\title{
The Effect of Unfocused versus Focused Metalinguistic Feedback on the Iranian EFL Learners' Use of Dependent Clauses in Writing
}

\section{Lida Zarearsanjani ${ }^{1} \&$ Laleh Fakhraee Faruji ${ }^{1 *}$}

\section{* Correspondence: \\ fakhraeelaleh@yahoo.com \\ 1.Department of English Language \\ Teaching, Shahr-e-Qods Branch, \\ Islamic Azad University, Tehran, Iran}

Received: 24 December 2020

Revision: 6 March 2021

Accepted: 2 April 2021

Published online: 20 June 2021

\begin{abstract}
This study attempted to investigate the effect of using focused vs. unfocused metalinguistic feedback on Iranian EFL learners' use of dependent clauses in writing. On the basis of an Oxford Quick Placement Test, 60 learners out of 90 intermediate female EFL learners with the age range of 17 to 27 from Melal language institute in Karaj were chosen to participate in the study. They were assigned to two experimental groups. The homogeneity of the two groups in terms of writing ability was determined by comparing their means in a writing pretest. The treatment was done through using focused feedback for the first experimental group and unfocused feedback in the second experimental group during 14 sessions. At the end of the treatment, a writing test was conducted as the posttest. The results of Paired Samples t-test showed that the participants in both experimental groups performed better in writing posttest. However, the results of one-way ANCOVA showed that there was no significant difference between the two groups' means on the posttest scores of achievements in accurate use of dependent clauses between two groups. The results were discussed in relation to some implications and recommendations for further research.
\end{abstract}

Keywords: dependent clauses, EFL learners, focused metalinguistic $\underline{\text { feedback }}$, unfocused metalinguistic feedback, writing 


\section{Introduction}

Writing is one of the important skills in the process of learning a second or foreign language. In fact, it is usually considered as the most complicated skill for foreign language learners to learn (Namaziandost, Pourhosein Gilakjani, \& Hidayatullah, 2020; Sadeghi \& Mosalli, 2013). Fageeh (2011) stated that writing is a release for emotions and thoughts, and while writing skill slowly comes on the process of acquisition, yet it forms an important part of second or foreign language learning. Despite the shifts in instructional methods, a primary part of language teaching and learning is accuracy in writing, which is important to both learners and teachers (Ferris, 2006; Hyland \& Hyland, 2006; Salem, 2011). Having realized such importance, English as a Foreign Language (EFL) and English as a Second Language (ESL) teachers have long been seeking for ways to improve their way of teaching writing. One way which can help learners improve their writing skill is providing written corrective feedback, and in the recent years many studies have been carried out to investigate the nature of feedback and its role in L2 teaching and learning (Elhawwa, Rukmini, Mujiyanto, \& Sutopo, 2019; Namaziandost, Razmi, Heidari, \& Tilwani, 2020).

In addition, feedback is provided for information, which was given from the reader to the writer during the writing process and also after a piece of writing. According to Burke and Pieterick (2010), the goal of feedback is helping learners to increase their potential in various writing stages, to promote their knowledge about the strengths and fields of improvement, and to identify actions for improving performance. Indeed, second language writing scholars stated that feedback is considered as the greatest factor for "encouraging and consolidating learning" (Hyland \& Hyland, 2006, p. 92). Furthermore, Hyland and Hyland (2006) believed that feedback in writing is extensively important in the process of learning, and working in this field is really significant. Corrective feedback has an effective and useful role in language learning (Bitchener, 2012; Namaziandost, Nasri, \& Ziafar, 2019). Furthermore, written feedback is very important in all language learning process (Adam, 2003). Feedback is applied to express an idea or reflection about the achievement of person (Saeb, 2016). Brannon and Clarke (2006) argued that written corrective feedback is considered as the most significant used form of feedback on their written work and "it can be a powerful tool for helping students to move forward in their learning" (p. 84).

In fact, learners have enough time to compare their output with the received CF in writing. Furthermore, based on some studies (Ellis, Sheen, Takashima, \& Murakami, 2008; Sheen, 2007; Sheen, 2009), it is argued that written CF has the continuing efficiency rather than oral CF on accuracy improvement in writing new scripts. In contrast, it can be a challenging task for teachers to give corrective feedback to help students in the process of their writing (Adam, 2003; Namaziandost, Hosseini, \& Utomo, 2020). Since it is really difficult and time-consuming to provide feedback to students' writing, it is worth considering the most operational and effective way to react to errors.

In addition, Ellis (2008) declared that one kind of written corrective feedback is metalinguistic corrective feedback, where the teacher provides some sort of metalinguistic clues to the nature of errors. In addition, as stated by Ellis (2009), the metalinguistic corrective feedback includes giving learners some form of explicit comment about the nature of their errors. On the other hand, Ellis et al. (2008) classified written corrective feedback into two groups, namely focused and unfocused. In focused feedback, teacher chooses some specific errors to be corrected while in unfocused feedback, the teacher corrects all types of errors in students' writing (Ellis et al., 2008). According to Ellis et al. (2008), focused and unfocused feedback affects the improvement of student's second language writings.

The unfocused approach in written error correction moves the attention of the student to errors in writing and to new features of the target language too, through promoting more effective language learning (Corpuz, 2011; Frear \& Chiu, 2015; Pourhosein Gilakjani, Namaziandost, \& Ziafar, 2020). The evidence of researches revealed that unfocused correction of all student errors contributes to lower error rates (Chandler, 2003; Ferris, 2006) and accuracy development in the revision of a particular text (Van Beuningen, De Jong, \& Kuiken, 2012); others differently have announced for focused correction of specific error kinds (Ellis, Loewen, \& Erlam, 2006; Ferris, 2006; Namaziandost \& Shafiee, 2018; Sheen, 2007; Van Beuningen, 2010).

As Ellis et al. (2006) stated, an unfocused approach to presenting written error correction is not the most effective approach since L2 learners have a limited processing ability. They believe that demanding L2 learners to manage written error correction which covers a large number of linguistic features simultaneously can lead to a cognitive overload that may constrain the students from processing their received feedback. In contrast, a focused approach in written error correction proves more effective since L2 learners can examine multiple corrections of a single error. As a result of this, L2 learners obtain both a richer understanding regarding why what they wrote was erroneous and 
opportunities to achieve the correct form (Baghzou, 2011; Ellis, 2009; Namaziandost, Razmi, Tilwani, \& Pourhosein Gilakjani, 2021; Rezai, 2011).

\subsection{Statement of the Problem}

Generally, writing in the English language is one of the most difficult tasks for L2 learners to perform (Almasi \& Nemat Tabrizi, 2016; Gedion, Tati, \& Peter, 2016). Hyland (2003) announced that L2 learners mainly need great help as it comes to writing in English. L2 learners require a range of basic and complex linguistic, mechanical and rhetorical skills in order to produce a coherent and accurate piece of writing (Almasi \& Nemat Tabrizi, 2016). Made and Wuli Fitriati (2017) also pointed out that producing a coherent, fluent, extended piece of writing is possibly the most difficult thing to do in language and most native speakers can never master this. Besides, the researchers who worked as an English instructor for years have noticed that compared to the other language skills, writing is the one which is mostly disregarded by both students and teachers. Also, it is observed that a noticeable number of teachers are not familiar with suitable techniques to help their students improve their writing ability. Furthermore, the majority of students who are at higher levels of L2 learning cannot use accurate grammar needed for acceptable writing. A great concern of the researcher is nature of the procedures which adopted by the teachers in writing a correction and giving feedback

Indeed, written corrective feedback is viewed as an important part of the language writing instruction since it permits an individualized teacher-to-student communication, which is hardly possible in the daily operations of an L2 writing class (Namaziandost \& Nasri, 2019). While many researchers questioned the effectiveness of providing written error correction (Bitchener, 2008; Truscott \& Hsu, 2008), others assumed that answering through written corrective feedback helps to improve their students' L2 writing accuracy (Brown, 2007; Hyland \& Hyland, 2006). There are different viewpoints among researchers about whether language students should be provided with feedback on their grammar in writing or not and whether feedback can be influential in writing or not. There has been a controversy among researchers regarding feedback. For example, Truscott (2007) and Bangert-Drowns et al. (2016) believed that corrective feedback is not useful and even it may cause more anxiety in learners. In fact, Truscott declared that CF is seen as both ineffective and potentially harmful.

On the contrary, Ferris (2004) declared that feedback is supportive and essential since most of learners are interested in the teachers' feedback. As Van Beuningen (2010) pointed out, for L2 learners, error cannot be ignored, but how to overcome the occurrence of errors is determined by the way they are provided with feedback. Moreover, some researchers defined that CF is concerning value in promoting grammatical accuracy (Bitchener \& Knoch, 2008a; Chandler, 2003; Sheen, 2007; Sheen, 2014). Additionally, Adams (2003) emphasized the benefit of written CF over oral forms. In fact, learners have enough time to compare their output with the received $\mathrm{CF}$ in writing. Furthermore, based on some latest studies (Ellis et al, 2008; Neisi, Hajijalili, \& Namaziandost, 2019; Sheen, 2007; Sheen, Wright, \& Moldawa, 2009), it was argued that written CF has the continuing efficiency rather than oral CF on accuracy improvement in writing new scripts.

In contrast, it can be a challenging task for teachers to give corrective feedback to help students in the process of their writing (Adam, 2003; Etemadfar, Namaziandost, \& Banari, 2019). Since it is really difficult and time-consuming to provide feedback to students' writing, it is worth considering the most operational and effective way to react to errors. The variety of strategies for achieving written CF makes this issue even more controversial. It questions both whether $\mathrm{CF}$ is effective and which type is more effective. Until currently, not enough studies have examined the differential effects of focused and unfocused written CF. They have displayed that focused CF is facilitative of learning and so have evidence to discredit the critics of written CF (Bitchener, 2008; Namaziandost, Abdi Saray, \& Rahimi Esfahani, 2018; Sheen, 2007). More particularly, Sheen (2007) suggest that written CF works as it is intensive and concentrated on a specific linguistic problem. Basically, her study formed a challenge to the traditional, unfocused approach to correct written errors in the writing of students.

In addition, Sheen et al. (2009), and Ellis et al. (2008) are those scholars who pointed out the effectiveness of focused and unfocused feedback. Ellis et al. (2008) did not find any significant differences on the learners' accuracy achievement based on the focused and unfocused corrective feedback group. It is believed that the focused feedback can be more useful than unfocused, as the students prefer to be aware about the specific error; however, Sheen et al. (2009) confirmed the result of Ellis et al.'s (2008) research by stating that the focused feedback was more operative and useful than unfocused feedback. Nonetheless, they argued that one of the technical methods of Ellis et al.'s study was that focused and unfocused CF were not easily identified. Moreover, Truscott (1996, p. 94) believed "grammar correction has significant harmful effect" and he claimed that grammatical feedback should be excluded, although 
learners like and rely on correction feedback (Leki, 1991). It does not mean that the teachers should search for providing with it. Semke (1984) has also proved that students who are not provided with correct forms, write carefully than the other students who are given correction.

In English department, it seems that way of feedback or precise technique is not delivered to the teachers to help their students increase their writing ability. According to Ashwell (2000), teachers believed that correcting the learners' grammar in their writing will help them develop their writing accuracy. Based on the finding of the research on the effect of error correction in second language writing classes, it can be concluded that learners who give error feedback from their teacher improve in accuracy after a while (Ferris \& Roberts, 2001; Mirshekaran, Namaziandost, \& Nazari, 2018). Research (Chandler, 2003; Neisi, Nasri, Akbari, \& Namziandost, 2019) has also shown that learners are interested in error feedback because they believe that feedback can help them to improve their L2 writing capability.

Moreover, Sheen (2007) declared that the most operational and influential way to measure the effect of written corrective feedback is through dividing a single linguistic element of students' writing and concentrating on all feedback on the element. As a result, the researchers have decided to focus on the dependent clauses in this study. In addition to researcher's information on previous studies, no studies have been reported for the Iranian EFL learners the effect of feedback in the use of dependent clauses in writing. Put in other words and based on all above mentioned points regarding types of feedback, namely focused and unfocused, there is no study in literature which indicates the effect of focused and unfocused metalinguistic feedback on the Iranian EFL learners' use of dependent clauses in writing, therefore, the researchers were persuaded to conduct such a research. Moreover, it seemed necessary to carry out a study which intended to compare the effects of these two treatments on EFL learners' competence in using dependent clauses in writing, and to find which type of written corrective feedback might result in better achievements.

\subsection{Objectives of the Study}

The extent to which unfocused and focused metalinguistic feedback on the use of dependent clauses can play a role in helping L2 writers improve the accuracy of their writing continues to be an issue of interest to researchers and teachers since Truscott (1996) mounted a case for its abolition. While there is growing empirical evidence that written CF can successfully affect writing skill (Aghajani, 2018; Eshtiyaghi \& Pourhossein Gilakjani, 2021; Karimnia \& Heydari Gheshlagh, 2020; Yazdizadeh, Shakibaei, Namaziandost, 2020), it is unclear which feedback strategy is more effective. Some attention has been given to investigating whether certain types of written CF may be more effective than others, but the findings are not conclusive. Addressing these issues will require time and commitment on the part of a number of researchers. The study being reported in this article contributes to this agenda by investigating the differential effects of direct unfocused and focused metalinguistic feedback on the use of dependent clauses in writing. In other words, the objectives of this study are to determine:

1. If the use of dependent clauses in writing can be affected by focused metalinguistic feedback.

2. If the use of dependent clauses in writing can be affected by unfocused metalinguistic feedback.

3. If learners' utilization of dependent clauses in writing differentiated through using focused vs. unfocused metalinguistic feedback.

\section{Review of the Literature}

Due to the vital role of feedback, numerous studies have been done in this regard. To investigate the effect of student feedback on teaching methodology, Fogal (2010) carried out a research at a foreign language university in Japan. Students were asked to respond critically to three short works of fiction. Student feedback was obtained through questionnaires and one-on-one interviews with the instructor. The results revealed that learners prefer materials that engage meta-cognitive awareness, and demonstrated that this awareness leads to improved performance and higher levels of work-related student satisfaction. The results also showed that students are more content with activities that challenge them to think about material relative to their own experiences.

Moreover, Chawla and Thukral (2011) determined the effects of student feedback in developing teaching competence among student teachers. The study was conducted on ten student-teachers. The efficiency of employing all the selected skills has been calculated by using observation schedule cum rating scale for each skill. The efficiency has been found to be greater than $83 \%$ in case of all the student-teachers trained through student feedback. Thus, Student Feedback is found to be useful for developing five selected teaching skills (Skill of Introducing the Lesson, Skill of Explanation, Skill of Probing Questioning, Skill of Stimulus Variation, and Skill of Blackboard Writing). 
Farrokhi and Sattarpour (2011) reported the findings of a study that explored (1) whether direct written corrective feedback (CF) can help high-proficient L2 learners, who has already achieved a rather high level of accuracy in English, improve in the accurate use of two functions of English articles (the use of ' $a$ ' for first mention and 'the' for subsequent or anaphoric mentions); and (2) whether there are any differential effects in providing the two different types of direct written CF (focused and unfocused) on the accurate use of these grammatical forms by these EFL learners. They concluded that focused written $\mathrm{CF}$ is more effective than unfocused one, at least where English articles are concerned, in improving grammatical accuracy of high-proficient L2 writers and thus strengthens the case for teachers providing focused written CF.

Akkuzu (2014) focused on the investigation of the role of feedback based on self-efficacy belief sources in the reciprocal interaction of teaching performance and self-efficacy beliefs. The data for this study were collected in the form of semi-structured interviews from 6 volunteer 5th-grade chemistry student teachers. The results indicated that different types of feedback based on self-efficacy belief sources directly affected the student teachers' self-efficacy beliefs and teaching performance.

A study was done by Mulliner and Tucker (2015) to investigate and compare the perceptions of students and academics with regard to feedback practice. It highlights the perceptions of academics and students with regard to preferences for different types of feedback, timeliness of feedback, students' engagement and interest in feedback, quality feedback and satisfaction with current practice. The findings indicate a significant difference between staff and students in relation to the students' engagement and interest in feedback and satisfaction with current practice and feedback preference.

Moreover, Tabrizi and Ghaffari (2015) attempted to investigate the effect of focused vs. unfocused written teacher correction on grammatical accuracy of Iranian medical students. The results revealed that both types of teacher correction positively affected grammatical accuracy of the learners, however, the learners in Focused Written Teacher Correction group showed more significant improvement in their grammatical accuracy when compared with the learners in unfocused Written Teacher Correction group and the control group.

Guo (2015) also carried out another study with 157 Chinese EFL students at a university setting for 7 weeks. The results indicated that students who received WCF within 4 months outperformed those who did not receive any CF in the control group in the immediate posttest. In an Iranian EFL context, Khanlarzadeh and Nemati (2016) conducted a study to explore the effect of direct unfocused CF on the grammatical accuracy of elementary students. They reported that although experimental group outperformed the control group in revision writing tasks, no significant difference was seen in new pieces of writing after a one-month interval.

In additions, Zohdi and Ghafournia (2017) aimed at investigating the efficacy of written corrective feedback (CF) in improving Iranian EFL learners' grammatical accuracy. It compared the effects of focused and unfocused written CF on the learners' grammatical accuracy. The results indicated a significant improvement in accuracy for the two experimental groups from pretest to posttest. The outcomes demonstrated that giving written $\mathrm{CF}$ was effective, which enhanced learners' grammatical accuracy, and that focused and unfocused written CF were not of differential significant effect in such manner.

Furthermore, Farjadnasab and khodashenas (2017) aimed to investigate the extent to which different types of WCF result in improved accuracy in writing over a period of two months, and then maintain to see if there is a differential effect on accuracy when the students are required to revise their writings based on the feedback provided to them over this period. After analyzing the collected data, it was found that providing WCF indeed contributes to the accuracy of the students' writings because the results indicated each type of feedback employed in the treatment groups could clearly bring about writing improvement at varying degrees. In particular, the findings suggested that direct feedback might bring about greater effects on students' writing accuracy, whereas different types of feedback are more likely to produce rather long-term improvement and/or learning over time.

Zarei, Ahour, and Seifoori (2018) attempted to investigate whether different CF strategies, including implicit, explicit, and emergent CF, can differently affect the accuracy and fluency of oral production among Iranian EFL learners. In addition, it explored the learners' attitudes towards how they felt about the CF types applied in the classroom. The results of inferential statistics indicated significant differences among the feedback types in both past-tense and futuretense accuracy. Moreover, the Emergent group had a better performance compared with the other groups with respect to accuracy. However, no significant difference was revealed among the feedback types with respect to fluency. The 
results of the content analysis also indicated that the learners mostly preferred to receive emergent feedback and participate in the process of error correction.

Soleimani and Modirkhamene (2020) investigated the effect of various CF types (i.e., comprehensive, selective, and no feedback) on advanced EFL learners' writing in different writing conditions (i.e., individual \& collaborative). Findings indicated that: (1) CF, especially selective one, was more effective in enhancing learners' writing accuracy, and (2) members of the collaborative writing groups outperformed those in the individual ones in terms of their writing accuracy development.

Moreover, Gharanjik and Ghoorchaei (2020) aimed at investigating the effect of metalinguistic explanation (ME) corrective feedback as a form focused instruction on Iranian high school students' use of the hypothetical conditional in their writing. Fifty high school students were given the Oxford placement test. Based on the results, 34 of them were chosen to be homogenous in terms of language proficiency. The students were then randomly assigned to two groups, one experimental and one control group. The experimental group received the treatment (ME) after each guided writing practice but the control group did not. The results of independent samples t-test showed that students in the experimental group significantly outperformed students in the other group in the accurate use of the grammatical feature.

Although numerous studies have dealt with feedback so far, the effect of unfocused versus focused metalinguistic feedback on the use of dependent clauses in writing did not receive enough attention as it deserves. Moreover, rare studies have been done in the context of Iran on checking the possible impact of unfocused versus focused metalinguistic feedback on writing. To fill out this gap, the following research questions were raised:

RQ1. Does using focused metalinguistic feedback have any statistically significant effect on Iranian EFL learners' use of dependent clauses in writing?

RQ2. Does using unfocused metalinguistic feedback have any statistically significant effect on Iranian EFL learners' use of dependent clauses in writing?

RQ3. Is there any statistically significant difference between the effect of using focused vs. unfocused metalinguistic feedback on Iranian EFL learners' use of dependent clauses in writing?

Based on the above research questions, the following research null hypotheses were formulated:

H01. Using focused metalinguistic feedback does not have any statistically significant effect on Iranian EFL learners' use of dependent clauses in writing.

H02. Using unfocused metalinguistic feedback does not have any statistically significant effect on Iranian EFL learners' use of dependent clauses in writing.

H03. There is no statistically significant difference between the effect of using focused vs. unfocused metalinguistic feedback on the Iranian EFL learners' use of dependent clauses in writing.

\section{Methodology}

\subsection{Design of the Study}

Quasi-experimental method of research was used in this study. Accordingly, the study employs a pre-test and posttest design to extract needed data of two experimental groups. This study focused on the variables of focused vs. unfocused metalinguistic feedback as two independent variables and the use of dependent clauses in writing as the dependent variable which is hypothesized to be affected by the independent variable. The collected data were analyzed quantitatively through using Independent and paired samples t-tests and one-way ANCOVA.

\subsection{Participants}

To do this study, 60 Iranian intermediate EFL learners were selected among 90 students at Melal Language Institute in Karaj. Participants were all female and their age ranged from 17-27 (with the mean range of 22). They have been studying English as a foreign language for at least 3 years. Their level of English language proficiency was determined on the basis of their scores on the Oxford Quick Placement Test (OQPT). The participants were selected based on convenience sampling method. They were randomly assigned to 6 classes. Three of these classes, containing 30 homogenous participants, were considered as experimental group one and the other three classes, containing 30 
homogenous participants, were considered as experimental group two. The experimental group one received focused metalinguistic feedback as their treatment and the other experimental group received unfocused metalinguistic feedback.

\subsection{Instruments and Materials}

\subsubsection{Oxford Quick Placement Test (OQPT)}

The first instrument which was utilized in the present study to homogenize the participants was a proficiency test. Oxford Quick Placement Test (OQPT) was administrated among 90 students to determine their English language proficiency (i.e., beginner, elementary, pre-intermediate, intermediate, and advanced). Based on the students' performance in this test, those whose scores were between 30 and 47 (out of 60) were considered as the intermediate learners and were selected as the target participants of the control and experimental groups.

\subsubsection{Writing Pretest}

The second instrument which was used in this study was a writing pre-test. Before the treatment, the researchers asked the participants to write a narrative composition about 200 words on a topic given by the researchers. The purpose of the writing pretest was to determine whether or not the participants were homogeneous in their writing ability. The validity of the pre-test was confirmed by two English experts and its reliability was calculated through using interrater reliability by means of Pearson correlation analysis $(\mathrm{r}=0.91)$

\subsubsection{Writing Posttest}

At the end of the treatment, the researchers selected a topic based on their textbook as the posttest for both groups and they were supposed to write a composition including at least 200 words like the pretest. The purpose of the post-test was to compare the performance of the experimental groups after the treatment. It should be noted that the validity of the post-test was confirmed by two English experts and its reliability was calculated through using inter-rater reliability by means of Pearson correlation analysis ( $\mathrm{r}=0.88)$

\subsubsection{T-Unit Rubric}

Larsen Freeman (2006) conducted a survey on in-depth analysis of learners' performance through objective assessment. Based on this, Larsen-Freeman (2006) introduced a profile which utilized T-units in assessing both oral and written language productions, in terms of accuracy, fluency, and complexity, of five Chinese learners of English. Freeman (2006) defined writing accuracy as the proportion of error-free T-units to total T-units (in terms of lexical, morphological, and syntactic errors). A T-Unit is a measurement in linguistics which refers to a main clause plus any subordinate clauses that may be attached to it. As defined by Hunt (1965), the T-unit, or minimal terminable unit of language, was intended to measure the smallest word group that could be considered a grammatical sentence, regardless of how it was punctuated. T-units are often used in the analysis of written and spoken discourse as they have been proven to show strong correlations with proficiency (Ellis \& Barkhuizen, 2005). The concept of T-unit was defined as "one main clause with all subordinate clauses attached to it" (Hunt 1965, p. 20). As mentioned before, Polio's (1997) guidelines for T-units were used in the analyses of the compositions. This means that, Polio's guideline was used first in order to determine T-units.

\subsubsection{The Course book}

The course book used by two groups was the same in the present study. The course book was American English File Book 2 (2008). This textbook is taught at Melal Language institute to intermediate learners, which contains nine units and mainly focuses on four skills suitable for intermediate students. The book is accompanied a CD to practice the pronunciation and a workbook. In this study, the students worked on the first four units of the book.

\subsection{Data Collection Procedure}

To carry out this study, First OQPT was administered in order to manifest the participants' homogeneity in terms of English language proficiency. Sixty participants out of 90 were chosen for the target population of the present study. The participants were then randomly assigned to two equal groups of experimental and control. In the following session, the participants were asked to take part in a writing pretest to write a narrative type text. The participants had 40 minutes to write the composition. Their performances were scored objectively by two raters (the researcher and one of her colleagues holding an MA degree in TEFL) following Polio's (1997) guidelines for T-units. 
Therefore, to determine writing accuracy, the proportion of the error-free T-units to total T-units was calculated. The writings were scored by two raters and the mean of the scores were considered as the final score for each participant. Both groups received written corrective feedback on dependent clause only with the difference being that the first group received focused feedback whereas the second group received unfocused feedback. In both experimental groups, learners were asked to write a paragraph on a topic provided by the teacher each session in which the important and the new points on the dependent clauses were explained.

Dependent clause "needs another clause to form a complete grammatical construction" (Richards \& Schmidt, 2002, p. 162). Following the studies by Storch (2005) and Foster, Alan, and Gillian (2000), a dependent clause contains a finite or non-finite verb and at least one subject. Therefore, parts of sentences not containing a subject and a verb were not considered as clauses, but phrases. It is worth mentioning that the linguistic accuracy of the texts was measured by calculating proportions of error-free T-units to total number of T-units.

During the treatment sessions, the first experimental group received focused feedback. The teacher just corrected the learners' errors in the use of dependent clauses and underlined the errors and corrected them. Indeed, the teacher crossed out only the target form and provided the correct form solely for these errors. Then the teacher gave their papers back and the students were asked to study the corrections for five minutes. The teacher did not give any further comment on the corrections. The corrected texts were collected.

On the other hand, in the second experimental group, the teacher revised all types of errors made by the learners. In fact, the teacher provided the correct form for all linguistic errors by crossing out the errors and writing the correct forms above the errors. In each session, any previous writing task returned to the students and both groups were also given metalinguistic explanations for the errors they committed. The students had to rewrite the previous task based on the given feedback, and the teacher asked the participants to read their comments and suggestions, to implement them and to deliver it. It is worth noting that the treatment sessions were 14 sessions, each taking 90 minutes and just 30 minutes on the treatment. After the treatment, the students were supposed to sit in a writing test as the posttest. In fact, they were asked to write another text including at least 200 words like the pretest.

\subsection{Data Analysis}

After gathering the needed data through the aforesaid procedures, the data were analyzed and interpreted according to the objectives of the study. The data were analyzed with the help of Statistical Package for Social Science (SPSS) software. In order to check the normality of the data, Kolmogorov-Smirnov (K-S) test was used. Then, Independent and paired samples t-test and one-way ANCOVA were applied to measure the effectiveness of the treatment on improving the participants' use of dependent clauses in writing.

\section{Results}

Before conducting any analyses on the pretest and posttest, it was necessary to check the normality of the distributions. Thus, Kolmogorov-Smirnov test of normality was run on the data obtained from the above-mentioned tests. The results are shown in Table 1.

Table 1. Normality test for the scores of the pretest and post-test

\begin{tabular}{cccc}
\hline & \multicolumn{3}{c}{ Kolmogorov-Smirnov } \\
\cline { 2 - 4 } & Statistic & df & Sig. \\
\hline EG1 Pretest & .202 & 30 & .08 \\
EG1 Posttest & .173 & 30 & .07 \\
EG2 Pretest & .124 & 30 & .20 \\
EG2 Posttest & .150 & 30 & .08 \\
\hline
\end{tabular}

The $p$ values under the Sig. column in Table 1 determine whether the distributions were normal or not. Since all the $p$ values in Table 1 are larger than .05 , it could be concluded that the distributions of scores for the pretest and posttest 
obtained from EG1 and EG2 learners had been normal. It is thus safe to proceed with parametric test (i.e. Paired samples t-test and one-way ANCOVA in this case) and make further comparisons between the participating groups. To check the performance of both groups on the pretest, an independent sample $t$ test was run.

Table 2. Results of descriptive statistics comparing the pretest scores of both groups

\begin{tabular}{cccccc}
\hline & Groups & N & Mean & Std. Deviation & Std. Error Mean \\
\hline \multirow{3}{*}{ Pretest } & EG1 & 30 & 10.53 & 2.06 & .37 \\
& CG2 & 30 & 10.70 & 2.30 & .42 \\
\hline
\end{tabular}

In table 2, the descriptive statistics of both groups is presented. The means of both groups are almost equal. The EG1 mean score is 10.53 and the EG2 mean score is 10.70 . This means that both groups are somehow similar since they are homogeneous at the beginning of the treatment.

Table 3. Results of independent samples t-Test comparing the pretest scores of both groups

\begin{tabular}{|c|c|c|c|c|c|c|c|c|}
\hline & \multicolumn{2}{|c|}{$\begin{array}{l}\text { Levene's Test for } \\
\text { Equality of } \\
\text { Variances }\end{array}$} & \multicolumn{5}{|c|}{ t-test for Equality of Means } \\
\hline & & $\mathrm{F}$ & Sig. & $\mathrm{t}$ & $\mathrm{df}$ & $\begin{array}{l}\text { Sig. }(2- \\
\text { tailed) }\end{array}$ & $\begin{array}{c}\text { Mean } \\
\text { Difference }\end{array}$ & $\begin{array}{l}\text { Std. Error } \\
\text { Difference }\end{array}$ \\
\hline \multirow[t]{2}{*}{ Pretest } & $\begin{array}{l}\text { Equal variances } \\
\text { assumed }\end{array}$ & .78 & .37 & -.29 & 58 & .76 & -.16 & .56 \\
\hline & $\begin{array}{l}\text { Equal variances } \\
\text { not assumed }\end{array}$ & & & -.29 & 57.29 & .76 & -.16 & .56 \\
\hline
\end{tabular}

In Table 3, an independent samples t-test was used to show the scores of both groups on the pre-test. Since the Sig (.76) is greater than 0.05 , the difference between the groups is not significant at $(\mathrm{p}<0.05)$. In fact, they performed the same on the pre-test.

As the first research question of the study sought to figure out whether focused metalinguistic feedback has any significant effect on Iranian EFL learners' use of dependent clauses in writing or not, the pretest and posttest scores of the learners in the EG1 were compared using a paired-samples $t$ test.

Table 4. Results of descriptive statistics comparing the pretest and posttest scores of the EG1 learners

\begin{tabular}{ccccc}
\hline & Mean & N & Std. Deviation & Std. Error Mean \\
\hline EG1 Post & 14.96 & 30 & 2.18 & .39 \\
EG1 Pre & 10.53 & 30 & 2.06 & .37 \\
\hline
\end{tabular}

As Table 4 shows, the EG1 learners obtained the mean scores of 10.53 on the writing pretest and 14.96 on the writing posttest. In order to determine whether the difference between these two mean scores was statistically significant or not, the researchers needed to consult the paired-samples $t$ test table (Table 5). 
Table 5. Results of paired-samples T test comparing the pretest and posttest scores of the EG1 learners

\begin{tabular}{|c|c|c|c|c|c|c|c|c|}
\hline & \multicolumn{5}{|c|}{ Paired Differences } & \multirow[t]{3}{*}{$\mathrm{t}$} & \multirow[t]{3}{*}{$\mathrm{df}$} & \multirow{3}{*}{$\begin{array}{l}\text { Sig. (2- } \\
\text { tailed) }\end{array}$} \\
\hline & \multirow[t]{2}{*}{$\begin{array}{c}\text { Mea } \\
\mathrm{n}\end{array}$} & \multirow[t]{2}{*}{$\begin{array}{c}\text { Std. } \\
\text { Deviation }\end{array}$} & \multirow[t]{2}{*}{$\begin{array}{l}\text { Std. } \\
\text { Error } \\
\text { Mean }\end{array}$} & \multicolumn{2}{|c|}{$\begin{array}{l}\text { 95\% Confidence } \\
\text { Interval of the } \\
\text { Difference }\end{array}$} & & & \\
\hline & & & & Lower & Upper & & & \\
\hline $\begin{array}{l}\text { EG1 Post - } \\
\text { EG1 Pre }\end{array}$ & 4.43 & 3.36 & .61 & 3.17 & 5.68 & 7.21 & 29 & .00 \\
\hline
\end{tabular}

In Table 5, the single most important piece of information is the $p$ value under the Sig. (2-tailed) column. This $p$ value should be compared with the pre-specified significance level (i.e., .05) to see if the difference between the pretest and posttest scores had been statistically significant or not. As the $p$ value under the Sig. (2-tailed) column in Table 3 was smaller than the significance level $(.00<.05)$, it could be construed that the difference between the writing pretest $(M$ $=10.53)$ and writing posttest $(M=14.96)$ of the EG1 learners was of statistical significance. Thus, the first null hypothesis of this study, "Using focused metalinguistic feedback does not have any statistically significant effect on Iranian EFL learners' use of dependent clauses in writing", was rejected.

To find out whether using unfocused metalinguistic feedback has any significant effect on Iranian EFL learners' use of dependent clauses in writing or not, the pretest and posttest scores of the learners in the EG2 were also compared via a paired-samples $t$ test.

Table 6. Results of descriptive statistics comparing the pretest and posttest scores of the EG2 learners

\begin{tabular}{ccccc}
\hline & Mean & N & Std. Deviation & Std. Error Mean \\
\hline EG2 Post & 15.26 & 30 & 2.13 & .38 \\
EG2 Pre & 10.70 & 30 & 2.30 & .42 \\
\hline
\end{tabular}

The descriptive statistics in Table 6 display the fact that the EG2 learners improved from the mean score of 10.70 on the writing pretest to the mean score of 15.26 on the writing posttest. To find out whether the difference between the pretest and posttest scores of the EG2 learners was statistically significant or not, the researchers had to examine the paired-samples $t$ test table (Table 7).

Table 7. Results of paired-samples $\mathrm{T}$ test comparing the pretest and posttest scores of the EG2 learners

\begin{tabular}{|c|c|c|c|c|c|c|c|c|}
\hline & \multicolumn{5}{|c|}{ Paired Differences } & \multirow[t]{3}{*}{$\mathrm{t}$} & \multirow[t]{3}{*}{$\mathrm{df}$} & \multirow{3}{*}{$\begin{array}{l}\text { Sig. (2- } \\
\text { tailed) }\end{array}$} \\
\hline & \multirow[t]{2}{*}{ Mean } & \multirow[t]{2}{*}{$\begin{array}{c}\text { Std. } \\
\text { Deviation }\end{array}$} & \multirow{2}{*}{$\begin{array}{c}\text { Std. } \\
\text { Error } \\
\text { Mean }\end{array}$} & \multicolumn{2}{|c|}{$\begin{array}{l}95 \% \text { Confidence Interval } \\
\text { of the Difference }\end{array}$} & & & \\
\hline & & & & Lower & Upper & & & \\
\hline $\begin{array}{l}\text { EG2 Post - EG2 } \\
\text { Pre }\end{array}$ & 4.56 & 3.29 & .60 & 3.33 & 5.79 & 7.58 & 29 & .00 \\
\hline
\end{tabular}

Since the $p$ value under the Sig. (2-tailed) column in Table 7 was smaller than the significance level $(.00<.05)$, it could be understood that the difference between the writing pretest $(M=10.70)$ and writing posttest $(M=15.26)$ of the EG2 learners was statistically significant. Therefore, the second null hypothesis of this study, "Using unfocused 
metalinguistic feedback does not have any statistically significant effect on Iranian EFL learners' use of dependent clauses in writing" was rejected.

The final objective of the study was to see if there was any significant difference between the effect of using focused vs. unfocused metalinguistic feedback on Iranian EFL learners' use of dependent clauses in writing. To fulfil this objective, the researchers had to compare the vocabulary post-test scores of the EG1 and EG2 learners, for which an independent-samples $t$ test could be conducted. Nonetheless, to control for any possible pre-existing differences between these two groups, and compare their post-test scores accordingly, one-way ANCOVA was conducted.

Table 8. Descriptive statistics for comparing the post-test scores of the EG1 and EG2 learners

\begin{tabular}{cccc}
\hline Groups & Mean & Std. Deviation & N \\
\hline EG1 & 14.96 & 2.18 & 30 \\
CG2 & 15.26 & 2.13 & 30 \\
Total & 15.11 & 2.14 & 60 \\
\hline
\end{tabular}

In Table 8, it could be found that the post-test mean score of the EG2 learners $(M=15.26)$ was larger than the posttest mean score of the EG1 learners $(M=14.96)$. To find out whether this difference was a statistically significant one or not, the researchers had to look down the Sig. column and in front of the Groups row in Table 9.

Table 9. Results of One-Way ANCOVA for comparing the post-test scores of the EG1 and EG2 learners

\begin{tabular}{ccccccc}
\hline Source & $\begin{array}{c}\text { Type III Sum } \\
\text { of Squares }\end{array}$ & df & Mean Square & F & Sig. & $\begin{array}{c}\text { Partial Eta } \\
\text { Squared }\end{array}$ \\
\hline Corrected Model & 9.66 & 2 & 4.83 & 1.05 & .35 & .03 \\
Intercept & 680.39 & 1 & 680.39 & 148.29 & .00 & .72 \\
Pretest & 8.31 & 1 & 8.31 & 1.81 & .18 & .03 \\
Groups & 1.62 & 1 & 1.62 & .35 & .55 & .00 \\
Error & 261.51 & 57 & 4.58 & & & \\
Total & 13982.00 & 60 & & & & \\
Corrected Total & 271.18 & 59 & & & & \\
\hline
\end{tabular}

In Table 9, if you find the row labeled Groups in the leftmost column, and read across this row, under the Sig. column, you can find the $p$ value, which should be compared with the alpha level of significance (i.e., .05). The $p$ value here was larger than the alpha level of significance $(.55>.05)$, which indicates that the difference between the two groups of EG1 $(M=14.96)$ and EG2 $(M=15.26)$ on the writing post-test was not statistically significant. This means that unfocused metalinguistic feedback was not significantly more effective than focused metalinguistic feedback in improving the use of dependent clauses in writing although, as it was seen above, the mean score of the former was slightly larger than that of the latter, and these two methods of feedbacks were both effective and helped EFL learners experience improvement from writing pretest to writing post-test. Therefore, the third null hypothesis of this study, "There is no statistically significant difference between the effect of using focused vs. unfocused metalinguistic feedback on the Iranian EFL learners' use of dependent clauses in writing", was accepted.

\section{Discussion}

After collecting the data, the researchers analyzed them in order to find out the effectiveness of the treatment on the students' writing skill. The findings showed that both groups who received the instruction, i.e., focused and unfocused 
metalinguistic feedback had better performance on their post-test compared their pre-test. The results statistically revealed that both groups significantly did better on the post-test $(p<.05)$. Therefore, the results showed that focused and unfocused metalinguistic feedback appeared to have a great effect on the writing skill of EFL learners. In general, L2 instructors dedicate so much time and effort to providing written corrective feedback (WCF) on the writing of their students in order to develop their writing. In L2 learning, WCF is one of the most discussed questions. A great deal of study has been done to provide contrary evidence to Truscott's argument regarding the ineffectiveness of the WCF.

This research further supports the prior researches (Ellis et al., 2008; Frear \& Chiu, 2015) that have demonstrated educational benefit of both focused and unfocused corrective feedback. This research demonstrates how students of second language writing have benefited and may seek to benefit to a smaller degree from unfocused corrective feedback as well as focused corrective feedback, and that there are advantages to incorporating or proceeding to use these teaching techniques. Moreover, the result of this research appears to support the theories students' ways of learning are contribute by their cognitive styles. It seems to agree with the research by Ellis (2009) which indicates that cognitive styles are strongly linked to some of the linguistic knowledge measures. The students' mastery of linguistic awareness will be definitely affected by their cognitive styles.

In addition, the findings of this study are in line with Bangert-Drowns et al. (2016) who proved that feedback which included any type of elaborated information was consistently more helpful than feedback that informed learners whether their responses were correct or incorrect. The results are also congruent with Baghzou (2011) and Rezai (2011) who claimed that focused feedback is successful in enhancing the learners' writing. For example, Salem (2011) found that in their journal writing, students supplied focused feedback demonstrated progression in concepts, coherence, continuity, and expression.

Furthermore, Sheen (2007) found that supplying L2 writers with meta-linguistic input had a dominant long-term impact on her analysis of intermediate L2 writers. Sheen compared multiple forms of direct input and discovered that in her delayed post-test writing assignment, her L2 writers who received meta-linguistic clarification sustained the progress they had achieved in their immediate post-test writing task, while those who received direct error correction alone did not. In the other side, Bitchener and Knoch $(2008$, 2010), who researched lower proficiency writers, discovered little distinction between writers who received various forms of direct feedback. As a result, it is evident that additional investigation is required to assess the relative efficacy of all forms of indirect and direct feedback when provided to L2 writers of varying proficiency levels.

With respect to the role of feedback in language learning, the present findings support the findings of the previous research conducted by Ellis et al. (2008) tried to examine the significant difference in feedback efficacy of the focused and unfocused corrections in improving accuracy of English articles used in written tasks. The findings of the study indicated that there is no significant difference between the focused and unfocused groups in improving accuracy in the use of English articles. Likewise, the findings of the present study support the one done by Frear (2010) who examined the effect of focused and unfocused direct written corrective feedback on a new piece of writing. The results of his study indicated that both types of feedback were effective in new pieces of writing.

Similarly, the present findings are somehow different from those found by Farrokhi and Sattarpour (2011) who have done a study in order to investigate whether direct focused corrective feedback and direct unfocused corrective feedback caused any differential effects on the accurate use of English articles by EFL learners across two different proficiency levels (low and high). The statistical analysis indicated that focused group did better than both unfocused and control groups in terms of accurate use of English articles in both proficiency levels. This result can be explained by reason of uncontrollable intervening variables such as individual differences and learners' proficiency level,

Furthermore, the result of this study supports the one done by Karimi and Fotovatnia (2012) who examined the effect of differential effects of focused and unfocused written correction on the accurate use of 5 grammatical structures by adult intermediate EFL learners of English. The results of their study revealed that written correction feedback is of broad pedagogic value, and focused CF and unfocused CF can equally contribute to the grammatical accuracy in L2 writing.

Prior studies show that in general, summative feedback on the drafts of students are not efficient (Ferris, 1999). As McGarrell (2011) notes, students are often uncertain about how to use feedback to enhance their writings. This consensus is reinforced by the actions of the students in this study. Although learners did not entirely neglect feedback on the material, most did not edit their drafts on the basis of summative feedback from the teacher. In contrast, Ferris 
(1997), in her research, stated that constructive feedback on material almost contributed to improvements for the ESL students. The finding of Ferris (1997) also holds true for the present research, which showed that answering positively to the quality of the writing with encouragement results in more high-quality writing. Of course, this result confirms the conclusion of Cardelle and Corno (1981) that encouragement should be accompanied with proposals for development.

The result of the present study is somehow in line with those done by Nemat Tabrizi and Ghaffari (2015) who investigated the effect of focused vs. unfocused written teacher correction on grammatical accuracy of Iranian medical students. The results of their study revealed that both types of teacher correction positively affected grammatical accuracy of the learners, however, the learners in Focused Written Teacher Correction group showed more significant improvement in their grammatical accuracy when compared with the learners in unfocused Written Teacher Correction group and the control group. Since the students in the current study are medical students, maybe it is one of the reasons which results in the effectiveness of focused feedback over unfocused feedback in the English for Specific Purposes (ESP) courses.

Also, the result of the present study is in line with the one done by Zohdi and Ghafournia (2017) who investigated the efficacy of written corrective feedback (CF) in improving Iranian EFL learners' grammatical accuracy. The results of their study proved that there is a significant improvement in accuracy for the two experimental groups from pretest to posttest. The results confirmed that written CF was effective, which enhanced learners' grammatical accuracy, and that focused and unfocused written CF were not of differential significant effect in such manner.

\section{Conclusion}

In summary, considering the Iranian EFL learners' problems about writing skill and the dominant effect of written corrective feedback in the educational settings, it seems worthwhile to investigate the effectiveness of this type of feedback in the process of writing instruction. Moreover, the comparative effect of two types of metalinguistic corrective feedback, namely focused vs. unfocused feedback, on learners' use of dependent clauses in writing in an Iranian context has not been investigated yet, and this has been another reason for the researchers with the aim of conducting the present study. Based on the results obtained, it was concluded that focused metalinguistic feedback had a significant positive effect on EFL learners' use of dependent clauses in writing. In addition, focused metalinguistic feedback had a significant positive effect on EFL learners' use of dependent clauses in writing.

Moreover, there was no significant difference between the impacts of focused and unfocused metalinguistic feedback on EFL learners' use of dependent clauses in writing. Furthermore, the results revealed that both experimental groups performed in their posttest than pretest. In fact, the present findings with respect to the effect of focused and unfocused feedback are in line with reference to Schmidt's hypothesis of the nature and the role of awareness in second language learning. According to Schmidt (1990), two levels of awareness can be distinguished, namely, noticing and understanding or metalinguistic awareness, with the latter being a higher level of awareness. While noticing involves attention to only the surface structure of sentences, attending to the underlying rules and principles occurs at the level of understanding. Therefore, it might be the case that these two types of feedback stimulate awareness at the level of noticing, and it might be the major promoter of metalinguistic awareness, hence contributing to the higher level of accuracy in both groups.

\subsection{Implications and Limitations of the Study}

From the pedagogical point of view, these results are encouraging for L2 teachers because they show that by giving unfocused versus focused metalinguistic feedback, even highly proficient L2 learners can improve their mastery of linguistic features that tend to emerge in their written texts. Furthermore, as demonstrated by this report, teachers should be assured that giving feedback on particular practical uses of a restricted amount of rule-based elements (focused CF) is more successful and enables high-proficient learners develop better in efficient usage of English articles than repairing all of the current errors from various grammatical features in learners' one piece of writing. While further research needs to be done for clarification, we can also discover that other, rule-based linguistic objects may be handled in the same manner with ease. We would not like to generalize this result to other linguistic systems or types based on the data presented in this analysis until further research is conducted to examine the usefulness of written $\mathrm{CF}$ in handling such structures and forms.

Moreover, educators of EFL and ESL should get a better picture of what types of feedback is the most effective to provide to the students. The results clearly show that these two types of feedback generally can help students improve 
their writing skills. However, there are differences in what type of feedback is the most effective and this may differ from country to country and probably even from student to student, depending on their proficiency level and personal motivation. Therefore, teachers need to be aware of that tailoring feedback is an important part of their work and what we need to do is to continue the longitudinal research on feedback to get closer to an answer.

This study outlined the two types of written corrective feedback on Iranian EFL learners' use of dependent clauses in writing. Based on the findings of the present study, the following implications regarding using focused vs unfocused feedback can be provided that are hoped to be helpful. The present study findings are hoped to provide EFL teachers with applicable and motivating ways for presenting writing to their learners. Correspondingly, teacher trainers may devise and plan courses through which teacher trainees become familiar with how to employ these two types of feedback which best help students improve their writing process. Learners are still facing difficulties in the process of learning which have great influence on their performance. The opportunity to work in a learning environment can help the students to learn and practice a new and different way of learning that ultimately enhances their writing skill.

Moreover, the results of this study may be helpful for EFL learners to improve their writing skill by receiving these two types of feedback. Syllabus designers and materials developers may wish to enhance the quality of the materials with proper tasks to familiarize learners with these two types of feedback to empower EFL learners' writing ability. Incorporating such type of metalinguistic corrective feedback, namely focused vs unfocused feedback, as part of the instruction can be very helpful to learners in language program.

Like all studies, this study had limitations and could not include all the issues related to the topic. They are as follows: The present study employed these two types of feedback to investigate their effect on EFL learners' use of dependent clauses in writing. Further studies may be needed to investigate the effectiveness of the same type of feedback on the learning of other language skills or components. In addition, this study was done among female students. More researches could have been done to see whether the gender would be a significant factor or not. Besides, this study has been done in language institutes; further studies can be conducted in different contexts such as high school.

Furthermore, this research was carried out with EFL learners at language institute with the range of 17-27; the same experiment could be carried out with other age groups to see whether age is a determining factor in writing. Also, the linguistic errors targeted in this study were considered dependent clauses in writing, researchers could replicate the study with other linguistic categories. Lastly, it seems that focused or unfocused feedback are useful for students of all proficiency levels, but further research is needed to investigate how these two types of feedback are applicable in different language areas.

\section{References}

Adams, R. (2003). L2 output, reformulation and noticing: implication for IL development. Journal of Language Teaching and Research, 7(3), 347-376. doi:10.1191/13621688031r127oa

Aghajani, M. (2018). Types of intelligences as predictors of self-efficacy: A study on Iranian EFL students. International Journal of Research in English Education (IJREE), 3(4), 12-26. doi:10.29252/ijree.3.4.12

Akkuzu, N. (2014). The role of different types of feedback in the reciprocal interaction of teaching performance and self-efficacy belief. Australian Journal of Teacher Education, 39(3), 37-67. doi:10.14221/ajte.2014v39n3.3

Almasi, E., \& Tabrizi, A. R. N. (2016). The effects of direct vs. indirect corrective feedback on Iranian EFL learners' writing accuracy. Journal of Applied Linguistics and Language Research,3(1), 74-85. http://www.jallr.com/index.php/JALLR/article/viewFile/237/pdf237

Ashwell, T. (2000). Patterns of teacher response to student writing in a multiple-draft composition classroom: Is content feedback followed by form feedback the best method? Journal of Second Language Writing, 9(3), 227-257. doi:10.1016/S1060-3743(00)00027-8

Baghzou, S. (2011). The effects of content feedback on students' writing. Ankara Üniversitesi $\begin{array}{llr}\text { DilveTarihCoğrafyaFakültesi } & \text { Dergisi, } & \text { 169-180. }\end{array}$ http://dergiler.ankara.edu.tr/dergiler/26/1661/17733.pdf

Bangert-Drowns, R. L., Kulik, C. C., Kulik, J. A., \& Morgan, M. T. (2016). The instructional effect of feedback in test-like events. Review of Educational Research, 61(2), 218-238. https://doi.org/10.2307/1170535 
Bitchener, J. (2008). Evidence in support of written corrective feedback. Journal of Second Language Writing, 17(2), 102-118. doi:10.1016/j.jslw.2007.11.004

Bitchener, J. (2012). Written corrective feedback for L2 development: Current knowledge and future research. TESOL Quarterly, 46(4), 855-860. https://onlinelibrary.wiley.com/doi/abs/10.1002/tesq.62

Bitchener, J., \& Knoch, U. (2008). The value of written corrective feedback for migrant and international students. Language Teaching Research, 12(3), 409-431. doi:10.1177/1362168808089924

Brannon, V., \& Clarke, V. (2006). Using thematic analysis in writing. Qualitative Research in Writing, 3(2), 77-101. http://dx.doi.org/10.1191/1478088706qp063oa

Brown, D. H. (2007). Principles of language learning and teaching (5 ${ }^{\text {th }}$ ed.). NY: Pearson Educations, Inc.

Burke, D., \& Pieterick, J. (2010). Giving students effective written feedback. Mc Graw Hill: Open University Press.

Cardelle, M., \& Corno, L. (1981). Effects on second language learning of variations in written feedback on homework assignments. TESOL Quarterly, 15(3), 251-261. https://onlinelibrary.wiley.com/doi/abs/10.2307/3586751

Chandler, J. (2003). The efficacy of various kinds of error feedback for improvement in the accuracy and fluency of L2 student writing. Journal of Second Language Writing, 12(3), $267-296$. https://faculty.uscupstate.edu/dmarlow/718/Error\%20Correction\%20-\%20Chandler.pdf

Chawla, V., \& Thukral, P. (2011). Effects of student feedback on teaching competence of student teachers: A microteaching experiment. Contemporary Educational Technology, 2(1), 77-87. https://doi.org/10.30935/cedtech/6044

Corpuz, V. (2011). Error correction in second language writing: Teachers' beliefs, practices, and students' preferences (Doctoral dissertation). Queenland University of Technology, Faculty of Education. http://eprints.qut.edu.au/49160/

Elhawwa, T., Rukmini, D., Mujiyanto, J., \& Sutopo, D. (2019). Effect of focused and unfocused feedback on learners' writing accuracy within different gender and cultural background groups. Arab World English Journal (AWEJ), 10(3), 382-400. doi:10.24093/awej/vol10no3.27

Ellis, R. (2008). Principles of instructed second language acquisition. CAL Digest available at http://www.cal.org/resources/digest/instructed2ndlang http://www.cal.org/resources/digest/digest_pdfs/Instructed2ndLangFinalWeb.pdf

Ellis, R. (2009). A typology of written corrective feedback types. English Language Teaching Journal, 63(5), 97-107. https://doi.org/10.1093/elt/ccn023

Ellis, R., Leowen, S., \& Elram, R. (2006). Implicit and explicit corrective feedback and the acquisition of L2 grammar. Studies in Second Language Acquisition, 32(2), 335-349. https://eric.ed.gov/?id=EJ777394

Ellis, R., Sheen, Y., Murakami, M., \& Takashimi, H. (2008). The effects of focused and unfocused written corrective feedback in an English as a foreign language context. System, 36(2), 353-371. doi:10.1016/j.system.2008.02.001

Eshtiyaghi, E., \& Pourhossein Gilakjani, A. (2021). The effect of unit-of-translation on Iranian upper-intermediate EFL learners' achievement in bizarre news translation. International Journal of Research in English Education, 6(1), 77-93. http://ijreeonline.com/article-1-491-en.html

Etemadfar, P., Namaziandost, E., \& Banari, R. (2019). The impact of different output-based task repetition conditions on producing speech acts among Iranian advanced EFL learners. Theory and Practice in Language Studies, 9(12), 1541-1549. doi: http://dx.doi.org/10.17507/tpls.0912.10

Fageeh, I. A. (2003). Saudi college students' beliefs regarding their English writing difficulties (Unpublished doctoral dissertation). Indiana University, Pennsylvania. 
Farjadnasab, A., \& Khodashenas, M. (2017). The effect of written corrective feedback on EFL students' writing accuracy. International Journal of Research in English Education, 2(2), 30-42. http://ijreeonline.com/article1-41-en.html

Farrokhi, F., \& Sattarpour, S. (2011). The effects of focused and unfocused written corrective feedback on grammatical accuracy of Iranian EFL learners. Theory \& Practice in Language Studies, 1(12), 797-1803. doi: 10.4304/tpls.1.12.1797-1803

Ferris, D. R. (1997). The influence of teacher commentary on student revision. TESOL Quarterly, 31, 315-339. doi: $10.2307 / 3588049$

Ferris, D. R. (1999). The case for grammar correction in L2 writing classes. A response to Truscott (1996). Journal of Second Language Writing, 8(1), 1-11. https://doi.org/10.1016/S1060-3743(99)80110-6

Ferris, D. R. (2004). The grammar correction debate in L2 writing: Where are we and where do we go from here? (and what do we do in the meantime...?). Journal of Second Language Writing, 13(2), 49-62. doi: 10.1016/j.jslw.2004.04.005

Ferris, D. R. (2006). Does error feedback help student writers? New evidence on the shorthand long-term effects of written error correction. In K. Hyland \& F. Hyland (Eds.), Feedback in second language writing: Contexts and issues (pp. 81-104). Cambridge, UK: Cambridge University Press.

Ferris, D. R., \& Roberts, B. (2001). Error feedback in L2 writing classes: How explicit does it need to be? Journal of Second Language Writing, 10(3), 161-184. doi: 10.1016/S1060-3743(01)00039-X

Fogal, G. G. (2010). EFL literature studies: Student feedback on teaching methodology. Asian EFL Journal, 12(4), 114-129. https://www.asian-efl-journal.com/PDF/Volume-12-Issue-4-Fogal.pdf

Foster, P., Alan, T., \& Gillian, W. (2000). Measuring spoken language: a unit for all reasons. Applied Linguistics, 21(3), 354-357. https://doi.org/10.1093/applin/21.3.354

Frear, D. (2010). The effect of focused and unfocused direct written corrective feedback on a new piece of writing, college English. Issues and Trends, 3, 57-71. https://nccur.lib.nccu.edu.tw/bitstream/140.119/79949/1/4.pdf

Frear, D., \& Chiu, Y. (2015). The effect of focused and unfocused indirect written corrective feedback on EFL learners' accuracy in new pieces of writing. System, 53, 24-34. doi: 10.1016/j.system.2015.06.006

Gedion, A., Tati, J. S., \& Peter, J. C. (2016). A syntactic errors analysis in the Malaysian ESL learners' written composition. Journal of Applied Linguistics and Language Research,3(6), 96-104. http://www.jallr.com/index.php/JALLR/article/view/406

Gharanjik, N., \& Ghoorchaei, B. (2020). The impact of metalinguistic corrective feedback on Iranian EFL learners' acquisition of the hypothetical conditional. AJELP: The Asian Journal of English Language \& Pedagogy, 8(2), 27-38. doi:https://doi.org/10.37134/ajelp.vol8.2.3.2020

Guo, Q. (2015). The effectiveness of written CF for L2 development: A mixed-method study of written CF types, error categories and proficiency levels (Doctoral dissertation). Auckland University of Technology.

Hunt, K. W. (1965). Grammatical structures written at three grade levels. NCTE Research Report No. 3.

Hyland, K. (2003). Genre-based pedagogies: A social response to process. Journal of Second Language Writing, 12(1), 17-29. doi:10.1016/S1060-3743(02)00124-8

Hyland, K., \& Hyland, F. (2006). Contexts and issues in feedback on L2 writing: An introduction. In K. Hyland \& F. Hyland (Eds.), Feedback in second language writing contexts and issues (pp. 1-19). Cambridge, UK: Cambridge University Press.

Karimi, M., \& Fotovatnia, Z. (2010). The effects of focused vs. unfocused written teacher correction on the grammatical accuracy of Iranian EFL undergraduates. The Asian EFL Journal, 62, 117-141. https://www.asian-efl-journal.com/monthly-editions-new/the-effects-of-focused-vs-unfocused-writtenteacher-correction-on-the-grammatical-accuracy-of-iranian-efl-undergraduates/ 
Karimnia, A., \& Heydari Gheshlagh, N. (2020). Investigating culture-specific items in Roald Dahl's "Charlie and Chocolate Factory" based on Newmark's model. International Journal of Research in English Education (IJREE), 5(2), 1-12. doi:10.29252/ijree.5.2.1

Khanlarzadeh, M., \& Nemati, M. (2016). The effect of written corrective feedback on grammatical accuracy of EFL students: an improvement over previous unfocused design. Iranian Journal of Language Teaching Research, 4(2), 55-68. doi:10.30466/ijltr.2016.20365

Larsen-Freeman, D. (2006). The emergence of complexity, fluency, and accuracy in the oral and written production of five Chinese learners of English. Applied Linguistics, 27(4), 590-619. doi:10.1093/applin/aml029

Leki, I. (1991). The preferences of ESL students for error correction in college-level writing classes. Foreign Language Annals. 24(3), 203-218. https://onlinelibrary.wiley.com/doi/abs/10.1111/j.19449720.1991.tb00464.x

Made, S. I., \& Wuli Fitriati, S. (2017). The socio-cultural constraints in the implementation of politeness strategies in the interactions among English language education students. English Education Journal EEJ, 7(1), 19-25. https://journal.unnes.ac.id/sju/index.php/eej/article/view/14681

McGarrell, H. (2011). AILA matters: Writing teacher response (WTR). International Journal of Applied Linguistics, 21(1), 140-142. https://doi.org/10.1111/j.1473-4192.2011.00281.x

Mirshekaran, R., Namaziandost, E., \& Nazari, M. (2018). The effects of topic interest and 12 proficiency on writing skill among Iranian EFL learners. Journal of Language Teaching and Research, 9(6), 1270-1276. doi: http://dx.doi.org/10.17507/jltr.0906.16

Mulliner, E., \& Tucker, M. (2015). Feedback on feedback practice: perceptions of students and academics. Assessment \& Evaluation in Higher 266-288. https://www.tandfonline.com/doi/abs/10.1080/02602938.2015.1103365

Namaziandost, E., Abdi Saray, A., \& Rahimi Esfahani, F. (2018). The effect of writing practice on improving speaking skill among pre-intermediate EFL learners. Theory and Practice in Language Studies, 8(1), 1690-1697. doi: http://dx.doi.org/10.17507/tpls.0812.16

Namaziandost, E., Hosseini, E., \& Utomo, D. W. (2020). A comparative effect of high involvement load versus lack of involvement load on vocabulary learning among Iranian sophomore EFL learners. Cogent Arts and Humanities, 7(1). doi:10.1080/23311983.2020.1715525

Namaziandost E., \& Nasri, M. (2019). Innovative practices in L2 writing materials in the EFL classroom: Effect on writing enhancement and attitude to English course. Asian Journal of Research in Social Sciences and Humanities, 9(9), 1-12. doi:10.5958/2249-7315.2019.00017.0

Namaziandost, E., Nasri, M., \& Ziafar, M. (2019). Comparing the impacts of various inputs (I+1 \& I-1) on preintermediate EFL learners' reading comprehension and reading motivation: the case of Ahvazi learners. Asian. J. Second. Foreign. Lang. Educ, 4(13), 1-20. doi:10.1186/s40862-019-0079-1

Namaziandost, E., Pourhosein Gilakjani, A., \& Hidayatullah (2020). Enhancing pre-intermediate EFL learners' reading comprehension through the use of Jigsaw technique. Cogent Arts \& Humanities, 7(1), 1-15. doi:10.1080/23311983.2020.1738833

Namaziandost, E., Razmi, M. H., Heidari, S., Tilwani, S. A. (2020). A contrastive analysis of emotional terms in bednight stories across two languages: Does it affect learners' pragmatic knowledge of controlling emotions? Seeking implications to teach English to EFL learners. Journal of Psycholinguistic Research, 50(6), 645-662. https://doi.org/10.1007/s10936-020-09739-y

Namaziandost, E., Razmi, M. H., Tilwani, S. A., \& Pourhosein Gilakjani, A. (2021). The impact of authentic materials on reading comprehension, motivation, and anxiety among Iranian male EFL learners. Reading \& Writing Quarterly. https://10.1080/10573569.2021.1892001 
Namaziandost, E., \& Shafiee, S. (2018). Gender differences in the use of lexical hedges in academic spoken language among Iranian EFL learners: A comparative study. International Journal of Research in English Education (IJREE), 3(4), 63-80. http://ijreeonline.com/article-1-130-en.html

Neisi, L., Hajijalili, M., \& Namaziandost, E. (2019). The impact of using inverted classrooms on promoting extensive versus intensive reading comprehension among Iranian upper- intermediate EFL learners. Theory and Practice in Language Studies, 9(12), 1513-1523. doi:http://dx.doi.org/10.17507/tpls.0912.07

Neisi, L., Nasri, M., Akbari, S., \& Namziandost, E. (2019). The comparative effect of teacher-assigned topics and student-selected topics on Iranian upper-intermediate EFL learners' writing skill. Journal of English Language Teaching and Applied Linguistics, 1(1), 1-15. https://al-kindipublisher.com/index.php/jeltal/article/view/121

Nemat Tabrizi, H., \& Ghaffari, S. (2015). The effect of focused vs. unfocused written teacher correction on grammatical accuracy of Iranian medical students. Academic Research International, 6(2), 398-411. https://www.semanticscholar.org/paper/The-Effect-of-Focused-and-Unfocused-Direct-Written-

Frear/5171d58b6eec6dda1066ffd7e271d7b5e9b72e8f

Polio, C. G. (1997). Measures of linguistic accuracy in second language writing research. Language Learning, 47(1), 101-143. https://onlinelibrary.wiley.com/doi/abs/10.1111/0023-8333.31997003

Pourhosein Gilakjani, A., Namaziandost, E., \& Ziafar M. (2020). A survey study of factors influencing Iranian EFL learners' English pronunciation learning. International Journal of Research in English Education (IJREE), $5(2)$,

103-123. http://ijreeonline.com/article-1-395-en.html

Rezaei, M. (2011). A post-process approach: e-mail dialogue journal writing and its impact on quality and quantity of high school students' writing. Indonesian Journal of English Language Teaching, 7(1), 19-30. http://ejournal.atmajaya.ac.id/index.php/ijelt/article/view/1537

Richards, J. C., \& Schmidt, R. (2002). Longman dictionary of language teaching and applied linguistics (3 ${ }^{\text {rd }}$ Ed.). London: Pearson Education.

Sadeghi, K., \& Mosalli, Z. (2013). The effect of task complexity on the quality of EFL learners' argumentative writing. Iranian Journal of Language Teaching Research, 1(2), 115-134. http://ijltr.urmia.ac.ir/article_20445.html

Saeb, F. (2016). The effects of focused and unfocused written corrective feedback on the grammatical accuracy of beginner EFL learners. International Journal of Applied Linguistics \& English Literature, 3(2), 22-26. https://www.journals.aiac.org.au/index.php/IJALEL/article/view/1075

Salem, M. S. A. (2011). The effect of journal writing on written performance, writing apprehension and attitude of Egyptian English Majors. A Dissertation, Pensylvania State University.

Schmidt, R. W. (1990). The role of consciousness in second language learning. Applied Linguistics, 11(2), 129-158. https://doi.org/10.1093/applin/11.2.129

Semke, H. (1984). Effects of the red pen. Foreign Language Annals, 17(3), 195-202. https://doi.org/10.1111/j.19449720.1984.tb01727.x

Sheen, Y. (2007). The effect of focused written corrective feedback and language aptitude on ESL learners' acquisition of articles. TESOL Quarterly, 41(2), 255-283. https://doi.org/10.1002/j.1545-7249.2007.tb00059.x

Sheen, Y. (2014). Differential effects of oral and written corrective feedback in the ESL classroom. Studies in Second Language Acquisition, 32(2), 203-234. https://doi.org/10.1017/S0272263109990507

Sheen, Y., Wright, D., \& Moldawa, A. (2009). Differential effects of focused and unfocused written correction on the accurate use of grammatical forms by adult ESL learners. System, 37(4), 556-569. https://doi.org/10.1016/j.system.2009.09.002

Soleimani, M., \& Modirkhamene, S. (2020). Various corrective feedback types in collaborative vs. individual writing conditions. International Journal of Research in English Education, 5(3), 24-39. http://ijreeonline.com/article-1-352-en.html 
Storch, N. (2005). Collaborative writing: Product, process, and students' reflections. Journal of second language writing, 14(3), 153-173. https://doi.org/10.1016/j.jslw.2005.05.002

Truscott, J. (1996). The case against grammar correction in L2 writing classes. Language Learning, 46(2), 327-369. https://doi.org/10.1111/j.1467-1770.1996.tb01238.x

Truscott, J. (2007). The effect of error correction on learners' ability to write accurately. Journal of Second Language Writing, 16(4), 255-272. http://epi.sc.edu/ar/AS_4_files/Truscott\%202007.pdf

Truscott, J., \& Hsu, A. Y. (2008). Error correction, revision, and learning. Journal of Second Language Writing, 17(2), 292-305. doi:10.1016/j.jslw.2008.05.003

Van Beuningen, C. (2010). Corrective feedback in L2 writing: Theoretical perspectives, empirical insights, and future directions. International Journal of English Studies, 10(2), 1-27. doi:10.6018/ijes.10.2.119171

Van Beuningen, C. G., De Jong, N. H., \& Kuiken, F. (2012). Evidence of the effectiveness of comprehensive error correction in second language writing. Language Learning, 62(1), 1-41. https://doi.org/10.1111/j.14679922.2011.00674.x

Yazdizadeh, Z., Shakibaei, G., Namaziandost, E. (2020). Investigating the relationship between Iranian undergraduate TEFL learners' self-regulation and self-efficacy. International Journal of Research in English Education, 5(3), 12-23. http://ijreeonline.com/article-1-308-en.html

Zarei, M., Ahour, T., Seifoori, Z. (2018). The effects of implicit, explicit, and emergent oral feedback on Iranian EFL learners' accuracy, fluency, and attitude. Journal of Language Horizons, 2(2), 75-102. doi: 10.22051/lghor.2019.26029.1122

Zohdi Rad, M., \& Ghafournia, N. (2017). The effect of focused corrective feedback and attitude on grammatical accuracy: a study of Iranian EFL learners. International Journal of Foreign Language Teaching and Research, 4(15), 75-85. http://jfl.iaun.ac.ir/article_579695.html 